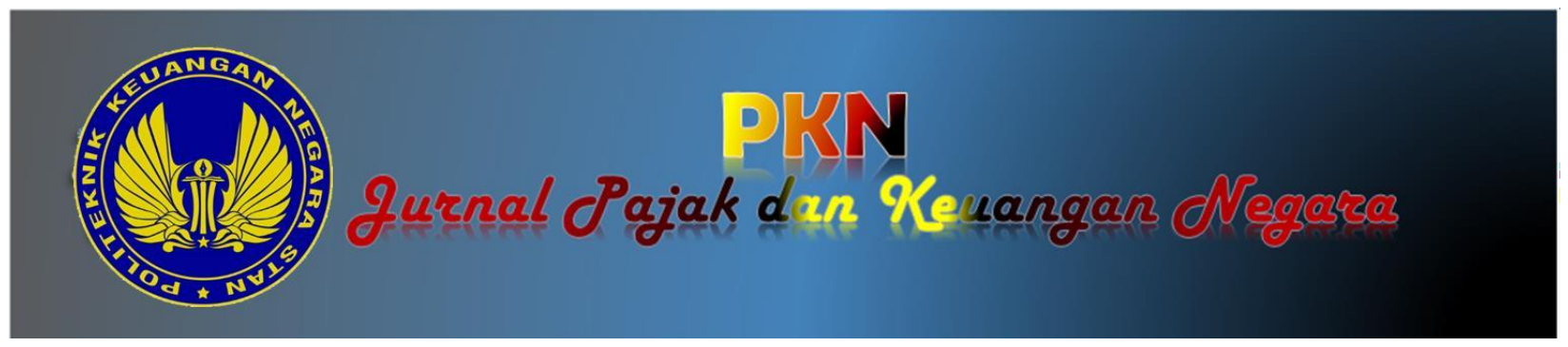

\title{
PENERAPAN FAIR VALUE ASET TETAP OLEH KANTOR PELAYANAN KEKAYAAN NEGARA DAN LELANG SORONG (STUDI KASUS PADA PENGADILAN AGAMA MANOKWARI)
}

\author{
${ }^{1}$ Amrie Firmansyah \\ ${ }^{2}$ Fadhil Maris Alamsyah \\ ${ }^{3}$ Eko Agus Purwanto \\ ${ }^{1-3}$ Politeknik Keuangan Negara STAN
}

\begin{abstract}
Alamat Korespondensi: ${ }^{1}$ amrie.firmansyah@gmail.com, ${ }^{2}$ fadhilalamsyah13@gmail.com, 3ekoguspur@gmail.com>
\end{abstract}

\section{INFORMASI ARTIKEL}

Diterima Pertama

[27 Februari 2020]

Dinyatakan Diterima

[20 Maret 2020]

KATA KUNCI:

Aset Tetap, Nilai Wajar, Penilaian Kembali.

KLASIFIKASI JEL:

$\mathrm{H} 2$

\section{ABSTRAK}

This study aims to analyze the implementation of the fair value concept of fixed assets to government agencies. The method in this study uses a qualitative approach with structured interviews. The informants in this study are three employees of the Services Office of State Wealth and Auction Sorong, who already have appraisal certificates. The object of this study uses the asset data of the manokwari district court in the form of land, buildings, and buildings, and water buildings during 2018. This study concludes that the implementation of the fair value concept in fixed assets by the Services Office of State Assets and Auction Sorong in broad outline is in accordance with applicable regulations or accounting standards, especially accounting standards related to fixed assets and fair value. Based on the results of this study are expected to encourage improvements in the process of inventory of fixed assets in the scope of government agencies and may make a positive contribution to the development of the implementation of fair value accounting in government sector.

Penelitian ini bertujuan untuk menganalisis penerapan konsep nilai wajar aset tetap pada instansi pemerintahan. Metode dalam penelitian ini menggunakan pendekatan kualitatif dengan wawancara terstruktur. Informan dalam penelitian ini adalah tiga pegawai Kantor Pelayanan Kekayaan Negara Dan Lelang Sorong yang telah memiliki sertifikat penilai. Objek penelitian ini menggunakan data aset pengadilan negeri manokwari berupa tanah, gedung dan bangunan, dan bangunan air selama tahun 2018.

Penelitian ini menyimpulkan bahwa penerapan konsep nilai wajar pada aset tetap oleh Kantor Pelayanan Kekayaan Negara Dan Lelang Sorong secara garis besar sudah sesuai dengan peraturan atau standar akuntansi terkait yang berlaku, terutama standar akuntansi terkait aset tetap dan nilai wajar. Berdasarkan hasil penelitian ini diharapkan dapat mendorong perbaikan proses inventarisasi aset tetap di lingkup instansi pemerintahan dan dapat memberikan kontribusi yang positif bagi perkembangan atas penerapan akuntansi nilai wajar dalam sektor pemerintahan. 


\section{PENDAHULUAN}

Sejak Undang-Undang Nomor 17 Keuangan Negara tahun 2003 tentang Keuangan Negara dan Undang-Undang Nomor 1 tahun 2004 tentang Perbendahaan Negara ditetapkan, pelaporan keuangan Pemerintah menjadi perhatian publik termasuk pelaporan terkait dengan aset Pemerintah. Selain kedua Undang-Undang tersebut, terdapat Peraturan Pemerintah Nomor 71 Tahun 2010 tentang Standar Akuntansi Pemerintahan yang mengatur secara spesifik atas standar pelaporan keuangan termasuk pengaturan teknis atas aset tetap yang juga banyak dikaitkan dengan barang milik negara. Standar akuntansi pemerintah yang lebih detail atas aset tetap Pemerintah diatur dalam Pernyataan Standar Akuntansi Pemerintahan (PSAP) Nomor 7 tentang Aset Tetap. Dalam aturan tersebut, pada tahun 2015 Pemerintah harus melaksanakan akuntansi berbasis akrual. Implikasi dari kewajiban tersebut, pemerintah harus menyajikan nilai aset di dalam neraca pemerintah sesuai dengan kondisi saat ini sehingga informasi tersebut dapat digunakan oleh pemangku kepentingan dalam pengambilan keputusan.

Sampai dengan saat ini, dalam menatausahakan aset tetap masih terdapat kendala yang dihadapi oleh Pemerintah. Opini Badan Pemeriksa Keuangan (BPK) atas laporan keuangan Pemerintah masih banyak menyoroti pengelolaan aset tetap dan permasalahannya. Ruang lingkup pemeriksaan sampai dengan penerapan penyusutan aset, kemungkinan besar berdampak negatif pada perubahan opini atas laporan keuangan yang disajikan pemerintah (Kahar, 2013). Tidak dapat dipungkiri bahwa penerapan akuntansi aset tetap tidak mudah khususnya pada saat perubahan perlakuan menjadi akuntansi berbasis akrual. Menurut Sinaga (2017), penerapan basis akrual membawa dampak positif yang hasil langsungnya terlihat dari menurunnya temuan terkait aset tetap dalam pemeriksaan BPK walaupun hal tersebut tidak sempurna untuk digunakan pada sektor pemerintahan. Sonbay (2010) menyatakan bahwa historical cost dapat digunakan dengan asumsi bahwa tidak terjadi perubahan harga atau unit moneter stabil. Namun, dalam kenyataannya nilai mata uang mengalami perubahan dari waktu ke waktu sehingga historical cost tidak dapat digunakan ketika terjadi inflasi. Fair value hadir untuk mengatasi beberapa permasalahan yang ada pada historical cost. Nugrahani (2014) menyatakan bahwa dengan kondisi pasar yang makin dinamis dan berkembang sangat cepat, konsep historical cost dianggap tidak cocok lagi, tidak relevan, karena tidak mencerminkan nilai pasar yang sebenarnya. Oleh karena itu, konsep fair value ditawarkan untuk menggantikan historical cost. Hal ini telah diberlakukan untuk standar akuntansi keuangan berbasis International Financial Reporting Standards (IFRS).
Fair value memiliki keunggulan bahwa laporan keuangan menjadi lebih relevan untuk dasar pengambilan keputusan, laporan keuangan dapat di perbandingkan, dan informasi mendekati keinginan pemakai laporan keuangan. Penatausahaan aset tetap Pemerintah di Indonesia telah melewati tahapan pencatatan, pemberlakuan peraturan untuk membentuk dana depresiasi, pencatatan aset tetap tanpa kewajiban melakukan penyusutan, dan saat ini pengaturan atas pencatatan aset tetap harus disajikan dengan akumulasi penyusutan (Hammam, 2017).

Penerapan nilai wajar pada aset tetap pemerintah juga telah diatur dalam Buletin teknis Nomor 9 tentang Akuntansi Aset Tetap dan Buletin teknik Nomor 15 tentang Akuntansi Aset Tetap Berbasis Akrual. Dalam kedua aturan tersebut, tidak diatur secara spesifik atas perlakuan aset tetap yang dinilai sesuai dengan nilai wajarnya. Teknis pengaturan nilai wajar pada aset pemerintah selanjutnya diatur dalam Peraturan Presiden Nomor 75 tahun 2017 tentang Penilaian Kembali Barang Milik Negara/Daerah.

Beberapa penelitian sebelumnya yang telah mengulas fair value atas aset tetap dilakukan oleh Apandi (2018) yang menyimpulkan bahwa penerapan nilai wajar yang dikelola oleh manajemen pajak aset perusahaan mempengaruhi biaya audit. Fajariana \& Aviyanti (2018) menyimpulkan bahwa akuntansi nilai wajar memiliki faktor pendukung utama yaitu kondisi pasar. Penerapan akuntansi nilai wajar dapat maksimal apabila kondisi pasar aktif karena situasi pasar yang aktif dapat memberikan informasi yang relevan dan reliabel. Khomsatun (2016) menyimpulkan bahwa tidak ada peningkatan daya banding laporan keuangan untuk kebijakan akuntansi yang diwajibkan menggunakan pengukuran nilai wajar. Kebijakan akuntansi yang diperbolehkan memilih metode pengukuran juga tidak terbukti terdapat penurunan daya banding laporan keuangan. Perbedaan daya banding terjadi hanya pada kebijakan akuntansi aset tetap yang mengalami kenaikan daya banding. Dengan menggunakan data data laporan keuangan perusahaan perbankan yang terdaftar di Bursa Efek Indonesia dari tahun 2012-2014, Pascayanti et al. (2017) menyimpulkan bahwa nilai buku dan nilai wajar aset dan nilai wajar liabilitas memiliki relevansi nilai.

Berbeda dengan penelitian sebelumnya yang banyak mengulas penerapan akuntansi nilai wajar untuk aset tetap terkait dengan perkembangan yang terjadi saat ini, penelitian ini bertujuan untuk mengulas implementasi penerapan aset tetap untuk barang milik negara. Ulasan atas penerapan nilai wajar masih jarang dilakukan dalam penelitian sebelumnya. Penelitian ini menggunakan objek aset tetap di pengadilan agama Manokwari yang menjadi salah satu satker dalam pembinaan KPKNL Sorong yang merupakan menjadi bagian dari Direktorat Jenderal 
Kekayaan Negara, Kementerian Keuangan. Instansi ini memiliki tugasu mengelola Barang Milik Negara berupa Aset Tetap yang tersebar di berbagai wilayah Indonesia agar terwujud proses pengelolaan BMN yang akuntabel. Data aset tetap menggunakan data tahun 2018 setelah Peraturan Presiden nomor 75 tahun 2017 ditetapkan.

\section{KERANGKA TEORI}

Nilai wajar merupakan suatu nilai yang diterima oleh seluruh pihak yang berkepentingan dalam transaksi tersebut, atau dengan kata lain nilai yang diakui oleh pasar, sehingga suatu aset dapat mempunyai nilai wajar yang berbeda dengan nilai bukunya (Kieso et al., 2017). Penelitian ini berfokus pada konsep nilai wajar atau fair value dalam penilaian suatu aset tetap. Penggunaan nilai wajar dalam menilai suatu aset pada dasarnya perlu kompetensi yang mumpuni sebagai penilai, jika tidak, penentuan nilai ini akan mengandung unsur subjektivitas yang tinggi dan dapat menimbulkan indikasi fraud. Dalam menentukan nilai wajar, penilai dapat menggunakan pendekatan tertentu, baik dari sisi nilai pasar, pendapatan ataupun biaya.

Aset tetap di sektor pemerintahan banyak dikaitkan dengan barang milik negara/daerah, sehingga memiliki peran vital dalam penyelenggaraan pemerintahan. Aset tetap merupakan aset yang memiliki bentuk fisik, masa manfaat lebih dari 12 (dua belas) bulan dan diperoleh untuk digunakan atau dimanfaatkan (PP 71, 2010). Dari ketiga karakteristik yang dimiliki oleh aset tetap tersebut dapat disimpulkan bahwa aset tetap pasti akan mengalami perubahan nilai seiring masa manfaat yang semakin mendekati akhir. Semakin besar perubahan nilai yang dialami, maka nilai aset tersebut akan mendekati Nilai sisa. Salah satu penyebab penurunan nilai tersebut adalah penyusutan yang tiap tahun terakumulasi.

Dalam Standar Akuntansi Pemerintah (2010), aset tetap disajikan di neraca berdasarkan biaya perolehannya dikurangi akumulasi penyusutan. Apabila terjadi kondisi yang memungkinkan penilaian kembali, maka aset tetap akan disajikan dengan penyesuaian pada masing-masing akun aset tetap. Penyesuaian nilai aset tetap dilakukan dengan berbagai metode yang sistematis sesuai dengan masa manfaat (PSAP 7, 2010). Metode penyusutan yang digunakan harus dapat menggambarkan manfaat ekonomik atau kemungkinan jasa (service potential) yang akan mengalir ke pemerintah. Nilai penyusutan untuk masing-masing periode diakui sebagai pengurang nilai tercatat aset tetap dan Diinvestasikan dalam Aset Tetap. Masa manfaat aset tetap yang dapat disusutkan harus ditinjau secara periodik dan jika terdapat perbedaan besar dari estimasi sebelumnya, penyusutan periode sekarang dan yang akan datang harus dilakukan penyesuaian. Metode penyusutan yang dapat dipergunakan antara lain metode garis lurus, metode saldo menurun ganda (double declining balance method), dan metode unit produksi (unit of production method) (PP 71, 2010). Tujuannya supaya penyajian laporan keuangan andal yang dapat digunakan sebagai pengambilan keputusan bagi pemangku kepentingan.

Dalam lingkup pemerintahan, aset tetap perlu untuk selalu diinvetarisasi dengan besaran atau nilai yang akuntabel agar memudahkan penyusunan laporan keuangan dan dapat dijadikan dasar hukum apabila terdapat rencana untuk melaksanakan pemanfaatan Barang Milik Negara (BMN) sesuai peraturan perundang-undangan yang berlaku. Inventarisasi aset tetap perlu dilakukan karena nilainya, kecuali tanah, pada umumnya akan mengalami penurunan akibat penyusutan. Penurunan nilai tersebut dapat dilihat dari aspek fisik maupun aspek ekonomi aset tersebut. Untuk aset tetap berupa tanah nilainya akan terus meningkat dikarenakan tingkat inflasi dan berbagai faktor lainnya. Oleh karena itu, data terkait suatu aset tetap seharusnya dapat selalu diperbaharui agar dapat memberikan gambaran tentang berapa nilai aset pada saat tertentu. Dalam lingkungan pemerintahan, pembaharuan tersebut dapat melalui sistem yang sudah disediakan DJKN selaku Pengelola Barang yaitu SIMAK BMN.

Penyusutan dijelaskan sebagai penyesuaian nilai sehubungan dengan penurunan kapasitas dan manfaat dari suatu aset. Penurunan kapasitas dan manfaat tersebut dapat disebabkan oleh pemakaian, keusangan atau lainnya. Aspek penyusutan diperlukan dalam menentukan historical costs suatu aset. Penyusutan umumnya terjadi pada Aset Tetap selain tanah. Dalam rangka melakukan pembaharuan nilai suatu aset, diperlukan data terkait nilai Penyusutan tiap tahunnya. Untuk dapat menghitung Penyusutan, terdapat prasyarat yang harus dipenuhi terlebih dahulu yaitu identifikasi aset yang kapasitasnya menurun, identifikasi nilai yang dapat disusutkan dan identifikasi masa manfaat aset tersebut.

Penilaian dan Penilaian Kembali atas BMN merupakan salah satu tugas dan fungsi Direktorat Jenderal Kekayaan Negara (DJKN), Kementerian Keuangan. Penilaian dan penilaian kembali akan menghasilkan suatu nilai atas suatu aset yang dapat mencerminkan nilai wajar aset tersebut. Dalam melaksanakan Penilaian dan Penilaian Kembali, terdapat 3 (tiga) pendekatan yang dapat digunakan yaitu pendekatan data pasar, pendekatan biaya dan pendekatan pendapatan. Dasar hukum pelaksanaan penilaian dan penilaian kembali oleh DJKN adalah Peraturan Presiden Nomor 75 Tahun 2017 dan Keputusan Direktur Jenderal Kekayaan Negara Nomor 367/KN/2019 sebagai pengaturan lebih lanjut terkait kegiatan tersebut. Adapun kegiatan revaluasi terdapat 3 (tiga) pendekatan yang dapat digunakan untuk mendapatkan nilai wajar. Pertama, pendekatan 
data pasar, digunakan dalam hal objek yang dinilai untuk mendapatkan nilai wajar adalah berupa tanah. Dalam metode ini, nilai dari objek penilaian berupa tanah dinilai berdasarkan harga pasar tanah per meter persegi pada satu kawasan yang sama dari objek penilaian tersebut dengan membandingkan nilai transaksi jual beli tanah yang telah terjadi pada satu kawasan sama atau yang paling dekat dengan objek penilaian tersebut. Data pembanding yang digunakan tersebut biasanya berjumlah lebih dari satu harga transaksi, kecuali keadaan lain tidak memungkinkan jumlah data pembanding lebih dari 1 (satu). Setelah data pembanding tersebut didapatkan, hal selanjutnya adalah melakukan penyesuaian atas keadaan tanah yang menjadi objek penilaian. Penyesuaian tersebut dilakukan berdasarkan keadaan tanah tersebut. Keadaan dimaksud dapat berupa lokasi, elevasi, kontur, akses menuju lokasi tersebut serta hal-hal lain yang dapat mempengaruhi nilai tanah tersebut apabila dilakukan transaksi jual beli.

Kedua, pendekatan biaya, digunakan dalam hal untuk menentukan nilai wajar suatu aset tetap berupa gedung dan bangunan. Dengan metode ini, penentuan nilai wajar didasarkan pada harga per meter persegi apabila bangunan tersebut dibangun pada masa sekarang dikurangi dengan penyusutan yang telah terjadi pada bangunan tersebut atau dapat di rumuskan dengan persamaan:

NW : NRC $-P$,

Dimana

NW : Nilai Wajar atas suatu Gedung dan Bangunan

NRC : biaya pembuatan/penggantian baru (new replacement cost) Gedung dan Bangunan

$P$ : Penyusutan

Dari persamaan tersebut, terdapat penyesuaian atas bangunan yang dibangun dengan bahan bangunan permanen, semi permanen maupun bangunan darurat. Untuk bangunan permanen NRC tersebut tetap, sementara NRC dikalikan dengan koefisien $50 \%$ untuk bangunan berupa semi permanen dan $25 \%$ untuk bangunan berupa bangunan darurat. New replacement cost (NRC) tersebut adalah nilai rupiah yang dibutuhkan apabila mendirikan bangunan yang sama pada masa sekarang. Oleh karena itu, nilai NRC bukanlah nilai yang tetap, namun nilai NRC tersebut dapat berubah-ubah tergantung dari beberapa faktor. Faktor tersebut antara lain adalah jenis material yang digunakan untuk membangun bangunan tersebut. Penggunaan material bangunan berupa hebel, bata merah, batako maupun jenis kayu akan memberikan nilai NRC yang berbeda. Satuan dari NRC tersebut adalah rupiah per meter persegi, sehingga penggunaan jumlah atau luas penggunaan material juga akan berubah. Selanjutnya nilai NRC tersebut juga akan berbeda di tiap-tiap daerah karena harga material yang digunakan untuk membangun bangunan tersebut berbeda pada tiap-tiap daerah sehingga nilai wajar bangunan juga akan berbeda di tiap-tiap daerah. Setelah didapatkan nilai NRC dari bangunan tersebut, nilai tersebut dikurangkan dengan penyusutannya. Penyusutan tersebut ditentukan dengan umur ekonomis bangunan tersebut atau memperhatikan waktu kapan bangunan tersebut diperoleh dengan memperhatikan adanya renovasi yang telah dilakukan apabila dilakukan renovasi. Ketiga, pendekatan pendapatan, digunakan untuk jenis bangunan khusus yang tidak dapat digunakan dengan dua pendekatan sebelumnya. Bangunan khusus tersebut diantaranya adalah hotel maupun bangunan yang secara khusus diperuntukkan untuk menghasilkan pendapatan.

\section{METODE PENELITIAN}

Penelitian in imenggunakan metode kualitatif dengan pendekatan studi kasus berdasarkan berbagai literatur yang dapat mendukung analisis isi atas kasus yang menjadi fokus bahasan. Informasi yang digunakan dalam penelitian ini berdasarkan wawancara terstruktur dengan informan sebagai 3 orang. Adapun pemilihan informan berdasarkan kompetensi sesuai dengan tujuan dari penelitian ini. Informan adalah pegawai KPKNL Sorong yang memiliki sertifikasi penilai. Adapun inti pertanyaan yang diajukan kepada informan adalah latar belakang melakukan penilaian aset tetap sesuai dengan nilai wajar, metode penilaian, proses penilaian, data dan informasi aset tetap yang dinilai.

Selain itu, data yang digunakan dalam penelitian ini juga didukung dengan laporan penilaian yang disusun oleh Kantor Pelayanan Kekayaan Negara dan Lelang Sorong pada tahun 2018 atas aset Pengadilan Negeri Manokwari berupa Tanah, Gedung Bangunan dan Bangunan Air. Literatur yang menjadi referensi dalam penulisan adalah peraturan-peraturan terkait standar akuntansi, penelitian-penelitian sebelumnya dan berbagai referensi lainnya.

\section{HASIL PENELITIAN}

KPNKL Sorong yang merupakan unit di bawah Direktorat Jenderal Kekayaan Negara, Kementerian Keuangan melaksanakan revaluasi dengan dasar hukum Peraturan Presiden Nomor 75 tahun 2017 tentang Penilaian Kembali Barang Milik Negara/Daerah. Proses revaluasi mengacu pada Standar Akuntansi Pemerintahan yang berlaku. Tujuan revaluasi aset adalah untuk penyusunan laporan keuangan pemerintah pusat, underlying aset untuk penerbitan SBSN, pembentukan basis data, mengetahui BMN Idle. Jika nilai Aset Tetap sudah diketahui secara pasti dengan menggunakan Nilai Wajar, maka proses pengelolaan BMN dapat berjalan lebih akuntabel dalam hal aset tersebut akan dilakukan Pemanfaatan BMN ataupun dalam rangka penyusunan laporan tertentu. Aturan penyajian nilai 
wajar telah ditetapkan dalam Standar Akuntansi Pemerintah Nomor 7 tentang Aset Tetap Tahun 2010.

Objek revaluasi DJKN berdasarkan Peraturan Presiden Nomor 75 Tahun 2017 tentang Penilaian Kembali BMN/D adalah berupa Tanah; Gedung dan Bangunan; dan Jalan, Irigasi dan Jaringan. Berdasarkan informasi yang diperoleh informan dalam penelitian ini, Kantor Pelayanan Kekayaan Negara dan Lelang Sorong (KPKNL Sorong) pada tahun 2018 telah melaksanakan kegiatan revaluasi atas Tanah, Gedung dan Bangunan dan Bangunan Air yang termasuk ke dalam kategori iii yaitu Jalan, Irigasi dan Jaringan.

Data yang menjadi fokus penelitian ini adalah data terkait aset tetap yang berada dalam penguasaan KPKNL Sorong yaitu aset tetap Pengadilan Agama Manokwari. Aset tetap Pengadilan Agama Manokwari terdiri dari 3 (tiga) bidang tanah, 2 (dua) bangunan berupa gedung, dan 1 (satu) bangunan air berupa saluran air. Sebelum dilakukan revaluasi, nilai aset tetap tersebut dicatat berdasarkan nilai perolehan dan setelah dilakukan penilaian revaluasi menghasilkan nilai seperti yang ditunjukan pada tabel berikut: Tabel 1 Hasil Revaluasi KPNKL Sorong Tahun 2018 (disajikan dalam rupiah)

\begin{tabular}{cccccc}
\hline No. & $\begin{array}{c}\text { Jenis } \\
\text { Aset } \\
\text { Tetap }\end{array}$ & $\begin{array}{c}\text { Tahun } \\
\text { Perole } \\
\text { han }\end{array}$ & $\begin{array}{c}\text { Nilai } \\
\text { Peroleha } \\
\text { n }\end{array}$ & $\begin{array}{c}\text { Nilai Wajar } \\
\text { Setelah } \\
\text { Revaluasi }\end{array}$ & Selisih \\
\hline $\mathbf{1}$ & Tanah NUP 1 & 1984 & 763.750 .000 & 3.823 .262 .000 & 3.059 .512 .000 \\
$\mathbf{2}$ & Tanah NUP 2 & 2013 & 1.200 .000 .000 & 2.304 .313 .000 & 1.104 .313 .000 \\
$\mathbf{3}$ & $\begin{array}{l}\text { Tanah } \\
\text { Bangunan }\end{array}$ & 2014 & - & 1.415 .491 .000 & 1.415 .491 .000 \\
$\mathbf{4}$ & $\begin{array}{l}\text { Rumah NUP } \\
\text { 1 }\end{array}$ & 1998 & 48.640 .000 & 263.757 .000 & 215.117 .000 \\
$\mathbf{5}$ & $\begin{array}{l}\text { Rumah NUP } \\
\mathbf{2}\end{array}$ & 2007 & 249.900 .000 & 289.145 .000 & 39.245 .000 \\
$\mathbf{6}$ & $\begin{array}{l}\text { Bangunan } \\
\text { Air }\end{array}$ & 2015 & 115.000 .000 & 122.449 .000 & 7.449 .000 \\
\hline
\end{tabular}

Sumber: Laporan Revaluasi KPKNL Sorong Tahun 2018

Berdasarkan tabel diatas dapat diketahui bahwa

nilai wajar dari aset tetap yang telah dilakukan revaluasi mengalami kenaikan wajar terhadap seluruh aset tetap yang ada pada Pengadilan Negeri Manokwari. Rincian informasi dari aset tersebut adalah sebagai berikut:

a. Tanah NUP 1

Tanah NUP tersebut diperoleh oleh satuan kerja pada tahun 1984 dengan luas total 1250 meter persegi dan Nilai Perolehan Rp 763.750.000 dan beralamat di Jalan S. Condronegoro, Manokwari, Papua Barat. Dari nilai tersebut, diketahui bahwa nilai tanah per meter persegi saat perolehan tanah pertama kali adalah Rp 611.000,- dan setelah dilakukan revaluasi, Nilai Wajar saat ini dari aset berupa tanah tersebut sebesar Rp 3.823.262.000,- atau Rp 3.058.609,6 per meter persegi. Kenaikan tersebut terjadi akibat beberapa hal diantaranya adalah lokasi yang strategis, kenaikan harga pasar tanah di wilayah tersebut, adanya inflasi nilai rupiah yang cukup signifikan dari tahun perolehan yaitu tahun 1984 sampai dilakukannya penilaian kembali atas aset tersebut yang dilakukan pada tahun 2018. Selain itu, aset tetap berupa tanah juga tidak mengalami penyusutan. Nilai tanah justru akan semakin naik dari waktu ke waktu. Penilaian Nilai wajar aset berupa tanah menggunakan pendekatan data pasar dengan data pembanding nilai transaksi atas aset tanah yang berlokasi dekat objek penilaian kembali tersebut.

\section{Tanah NUP 2}

Tanah NUP 2 diperoleh oleh satuan kerja pada tahun 2013 dengan luas 5000 meter persegi dan nilai perolehan sebesar $\mathrm{Rp} 1.200 .000 .000$,- atau $\mathrm{Rp}$ 240.000,- per meter persegi dan beralamat di Jalan Esau Sesa, Manokwari, Papua Barat. Nilai wajar aset tanah setelah dilakukan revaluasi adalah sebesar $\mathrm{Rp}$ 2.304.313.000,- atau sebesar Rp 460.862,-- per meter persegi. Metode penilaian yang digunakan untuk menentukan Nilai Wajar pada aset tanah tersebut menggunakan pendekatan pasar. Dimana Nilai Wajar yang terbentuk tersebut mengikuti nilai transaksi yang telah terjadi di sekitar area aset tersebut berada dan setelah dilakukan penyesuaian terhadap kondisi aset tanah tersebut. Kondisi tersebut diantaranya, lokasi, kemudahan akses dan kontur tanah.

b. Aset Bangunan Rumah

Setelah revaluasi dilakukan dalam rangka untuk menentukan nilai wajar, diperoleh nilai wajar untuk Rumah NUP 1 dengan luas 83 meter per segi dengan nilai Rp 48.640.000,- dan telah mengalami penyusutan dengan akumulasinya sebesar Rp 19.367.558,sehingga mempunyai Nilai Buku sebesar Rp 29.272.442,-. Nilai wajar setelah revaluasi sebesar Rp263.757.000 atau Rp 3.177.795,181,- per meter persegi. Kenaikan nilai wajar tersebut disebabkan oleh NRC yang mengalami kenaikan. Kenaikan NRC tersebut disebabkan oleh beberapa hal, yaitu kenaikan harga bangunan; inflasi mata uang dari tahun 1998 sampai 2018. Untuk bangunan rumah NUP 2 diperoleh oleh satker pada tahun 2007 dengan luas 70 meter persegi dan nilai perolehan sebesar Rp249.900.000,atau Rp 3.570.000,- per meter persegi. Aset tersebut telah mengalami Penyusutan selama masa manfaatnya sebesar Rp 54.978.000,- dan mempunyai Nilai Buku sebesar Rp 19.992.000,-. Setelah dilakukan revaluasi maka didapatkan nilai wajar sebesar $\mathrm{Rp}$ 289.145.000,- atau mengalami kenaikan nilai sebesar Rp 39.245.000,-. Kenaikan yang dialami oleh aset tersebut dikarenakan kenaikan nilai NRC. Kenaikan NRC tersebut akibat kenaikan harga material yang cukup signifikan yang terjadi di kawasan Manokwari dari tahun 2007 sampai dengan tahun 2018. Kenaikan harga material yang signifikan tersebut menyebabkan kenaikan Nilai Wajar pada aset yang dilakukan revaluasi. Hal itu karena perhitungan Nilai Wajar dilakukan menggunakan pendekatan biaya (cost approach).

c. Aset Bangunan Air

Aset bangunan air yang ada pada satuan kerja Pengadilan Agama Manokwari adalah jenis Bak penampung air dengan tahun perolehan 2015 dan nilai perolehan sebesar Rp115.000.000,-. Dalam 
kenyataannya, aset tersebut tidak disusutkan selama masa manfaatnya sehingga nilai buku yang tercatat pada tahun penilaian di tahun 2018 sebesar nilai perolehannya yaitu Rp 115.000.000,--. Setelah dilakukan revaluasi atas aset bangunan air tersebut dilakukan, didapatkan nilai wajar sebesar $\mathrm{Rp}$ 122.449.000,-. Perhitungan nilai wajar tersebut, tetap mengacu pada NRC. Perhitungan NRC pada bangunan ini dilakukan dua kali, yaitu NRC untuk menara air dan NRC untuk bak penampungnya. Akumulasi penyusutan dari aset tersebut ditentukan dengan melihat umur aset dari tanggal perolehan sampai dengan tanggal penilaian dibandingkan dengan kondisi aset tersebut menurut subjektifitas penilai. Kondisi aset tersebut terdiri dari 3 (tiga) kategori yaitu Baik, Rusak Ringan, Rusak Berat. Dari ketiga kategori kondisi tersebut, kondisi yang ditetapkan penilai atas aset tersebut adalah "Baik".

Berdasarkan penjelasan untuk tiap aset diatas, dapat dilihat bahwa penentuan Nilai Wajar terhadap BMN berupa Aset Tetap Gedung dan Bangunan yang dilakukan oleh DJKN menggunakan pendekatan biaya (cost approach). Dengan pendekatan tersebut, harga material yang digunakan apabila membuat bangunan yang serupa di masa sekarang menjadi unsur yang paling signifikan dalam mendapatkan nilai wajar. Hal tersebut juga yang menjadi alasan bahwa nilai wajar terhadap aset tersebut lebih besar dari nilai perolehannya meskipun penyusutan telah dilakukan atas aset tersebut. Pendekatan lain yang diterapkan adalah pendekatan data pasar untuk aset berupa tanah. Dalam menentukan Nilai Wajar aset tersebut, KPKNL Sorong membandingkan nilai aset dengan aset sejenis di kawasan yang sama sehingga didapatkan Nilai Wajar. Setelah mendapatkan nilai wajar dari perhitungan diatas, langkah selanjutnya adalah input Nilai Wajar yang baru tersebut kedalam aplikasi Penatausahaan BMN atau yang dikenal dengan SIMAK BMN dan SIMAN BMN. Kedua nilai wajar yang diinput harus sinkron pada dua aplikasi tersebut. Apabila proses input nilai wajar yang baru ke dalam aplikasi tersebut tidak sinkron akan menghasilkan nilai Aset Tetap yang tidak valid dan akurat pada Neraca di dalam Laporan Keuangan Pemerintah Pusat yang selanjutnya dapat memunculkan masalah baru terkait aset pemerintah.

Setelah nilai wajar diketahui dari proses revaluasi tersebut, nilai wajar yang didapatkan lalu diserahkan ke Badan Pemeriksa Keuangan (BPK) untuk dilakukan pemeriksaan agar nilai yang dihasilkan valid dan akurat sehingga nantinya hasil dari Penilaian Kembali atas BMN tersebut dapat membantu menghasilkan neraca yang lebih baik dan tepat secara Nilai Wajar khususnya untuk nilai BMN. Namun, menurut BPK hasil penetapan nilai wajar pada Penilaian Kembali BMN yang dilakukan oleh DJKN dan khususnya KPKNL Sorong tersebut juga membawa risiko masalah terkait nilai wajar aset tetap pada laporan keuangan.
Beberapa risiko tersebut antara lain berupa penilaian BMN tidak didukung dengan mekanisme validasi atas hasil inventarisasi, ketidaksesuaian metodologi penilaian dengan karakteristik BMN, penetapan masa manfaat baru hanya ditetapkan atas sebagian aset, hasil konfirmasi/penyesuaian harga tanah pembanding tidak didukung dengan dokumen pendukung, terdapat data inventarisasi aset tidak sesuai (dokumen sumber pendataan, kondisi fisik BMN, klasifikasi BMN seharusnya) dan proses Quality Assurance/Quality control (QA/QC) tidak dilakukan sebagaimana pada penilaian yang selama ini dilakukan. Keenam risiko masalah proses penilaian tersebut dapat berdampak pada Nilai Wajar yang tidak akurat dan valid sehingga menyebabkan berbagai masalah terkait Nilai Wajar BMN apabila dimasukkan kedalam Laporan Keuangan Pemerintah Pusat (LKPP). Penetapan nilai wajar tersebut dilakukan menggunakan alat bantu Penilaian bernama SiapGrak. Dalam alat bantu tersebut terdapat nilai Daftar Biaya Bangunan dan Gedung (DBBG) yang menjadi komponen dalam mendapatkan nilai NRC yang setelah dikurangi dengan penyusutannya akan menghasilkan Nilai Wajar Aset Tetap

Selain mengacu pada peraturan yang menjadi dasar hukum pelaksanaan revaluasi. KPKNL Sorong juga telah menerapkan konsep Nilai Wajar sesuai PSAK 68 (IAI, 2018). Kegiatan revaluasi yang dilaksanakan oleh KPKNL Sorong telah menerapkan prinsip-prinsip Nilai Wajar yang diatur pada PSAK tersebut. Salah satu konsep pengukuran Nilai Wajar berdasar PSAK 68 (IAI, 2018) adalah dalam mengukur nilai wajar, entitas memperhitungkan karakteristik kondisi dan lokasi aset pada tanggal pengukuran. Konsep ini dapat kita lihat dari revaluasi yang dilaksanakan oleh KPKNL Sorong atas Aset Tetap berupa Tanah. Selain memperhitungkan kondisi dan lokasi aset, PSAK 68 (IAI, 2018) juga mengasumsikan nilai wajar sebagai nilai yang sesuai dengan kondisi pasar pada tanggal pengukuran. Konsep ini dapat kita lihat dari revaluasi yang telah dilaksanakan oleh KPKNL Sorong dengan mempertimbangkan kondisi pasar saat ini melalui faktor tingkat inflasi. Nilai aset yang menjadi objek revaluasi KPKNL Sorong juga didapatkan baik secara observasi langsung ataupun diestimasi dengan teknik yang dalam konteks standar revaluasi yang berlaku di Indonesia terdapat 3 teknik yang dapat digunakan, yaitu teknik pendekatan data pasar, teknik pendekatan biaya ataupun teknik pendekatan pendapatan. PSAK 68 mengamanatkan suatu hierarki penentuan Nilai Wajar. Dalam menentukan Nilai Wajar, penilai dapat menggunakan pembanding harga suatu aset sejenis di pasar. Jika tidak terdapat pasar untuk aset tersebut maka diperlukan metode penilaian khusus seperti penggunaan transaksi antara pihak yang mengerti/berkeinginan, referensi atas nilai wajar terkini dari instrumen lain yang secara substansial sama, analisis arus kas yang didiskonto 
(discounted cash flow analysis); dan model penetapan harga opsi (option pricing model).

Hierarki penentuan Nilai Wajar berdasarkan standar tersebut telah diterapkan oleh KPKNL Sorong dalam melakukan revaluasi atas BMN Pengadilan Negeri Manokwari. Dalam menentukan Nilai Wajar aset berupa Tanah, KPKNL Sorong menggunakan perbandingan data nilai aset sejenis dalam wilayah yang sama, sedangkan dalam menentukan Nilai Wajar aset berupa Bangunan digunakan pendekatan biaya.

\section{KESIMPULAN DAN SARAN}

Penilaian Kembali BMN dalam bentuk aset tetap yang dilakukan oleh Kantor Pelayanan Kekayaan Negara dan Lelang (KPKNL) Sorong bertujuan untuk mendapatkan nilai wajar atas aset berupa tanah, rumah dan bangunan air sudah sesuai dengan mekanisme pelaksanaan penilaian kembali yang berlaku. Pendekatan penilaian yang menggunakan pendekatan pasar untuk aset berupa tanah yang dalam metode tersebut membandingkan harga BMN dengan harga transaksi jual beli tanah yang terjadi di satu kawasan yang sama menjadikan harga BMN sesuai dengan harga pasar pada umumnya sehingga Nilai Wajar yang terbentuk atas penilaian yang dilakukan tersebut menjadi akurat sesuai dengan kondisi pasar pada kawasan tersebut. Selanjutnya, penetapan nilai wajar terhadap Barang Milik Negara (BMN) yang berupa bangunan menggunakan pendekatan biaya (cost approach) dalam menetapkan nilai wajar tersebut juga telah sesuai dengan peraturan dan standar akuntansi keuangan yang berlaku. Kebijakan yang diambil oleh Direktorat Jenderal Kekayaan Negara (DJKN) dalam menggunakan pendekatan biaya untuk bangunan tersebut yang menjadikan Nilai Wajar aset bangunan lebih tinggi dari nilai perolehannya. Adapun pertimbangannya adalah terkait dengan Nilai New Replacement Cost (NRC) lebih tinggi dari nilai penyusutannya, Nilai Daftar Biaya Bangunan Gedung (DBBG), tingkat inflasi.

Dalam melaksanakan Penilaian Kembali, selain dengan mengacu kepada mekanisme pelaksanaan yang berlaku, KPKNL Sorong juga telah sesuai dengan standar akuntansi terkait konsep pengakuan Nilai Wajar pada Aset Tetap. Proses Penilaian Kembali juga mempertimbangkan tingkat inflasi yang terjadi di daerah tersebut. Oleh sebab itu, penentuan Nilai Wajar tersebut dapat dikatakan telah sesuai dengan metode yang diperkenankan oleh standar akuntansi. Adapun masalah terkait dengan proses penentuan Nilai Wajar saat Penilaian Kembali ini bukanlah dari segi metode maupun cara yang digunakan melainkan dari segi kegiatan paska dan pra revaluasi. Kegiatan tersebut antara lain adalah tidak sinkronnya nilai di aplikasi penatausahaan BMN serta kurangnya datadata pendukung dalam menentukan Nilai Wajar.

\section{IMPLIKASI DAN KETERBATASAN}

Penelitian ini dilakukan dengan menggunakan pendekatan wawancara dan analisis data dengan menggunakan ulasan literatur yang masih terbatas. Berdasarkan pembahasan dalam penelitian ini, pihak yang berkepentingan dalam penentuan Nilai Wajar BMN (termasuk auditor) perlu untuk menyepakati standar kegiatan penentuan nilai wajar. Penelitian ini diharapkan dapat memberikan kontribusi bagi penelitian di bidang akuntansi terkait konsep nilai wajar khususnya untuk akuntansi pemerintah sehingga dapat bermanfaat untuk terus meningkatkan kualitas laporan keuangan Pemerintah Pusat maupun Daerah.

\section{DAFTAR PUSTAKA (REFERENCES)}

Apandi, R. N. N. (2018). Pengaruh Penerapan Fair Value Non Current Asset Dan Manajemen Pajak Atas Asset Perusahaan Terhadap Fee Audit. Jurnal Riset Akuntansi \& Keuangan, 4(2), 12291242.

Hammam, M. (2017). Perjalanan Akuntansi Aset Tetap Pada Pemerintah Daerah Di Indonesia Dan Capital Charging Sebagai Wacana Pengembangannya. Jurnal Tata Kelola \& Akuntabilitas Keuangan Negara, 3(1), 21 - 31.

Kahar (2013). Penyusutan Aset Tetap dan Permasalahannya. Artikel Badan Pengawasan Keuangan dan Pembangunan. http://www.bpkp.go.id/\%20jateng/konten/190 8/Penyusutan-Aset-Tetap-Pemerintah-danPermasalahannya.bpkp diakses tanggal 23 Februari 2020.

Khomsatun, S. (2016). Penerapan Pengukuran Nilai Wajar PSAK-Konvergensi IFRS dan Dampaknya pada Pilihan Kebijakan Akuntansi di Indonesia. Jurnal Riset Akuntansi Dan Keuangan, 4 (2), 967984.

Direktur Jenderal Kekayaan Negara. Keputusan Direktorat Jenderal Kekayaan Negara Nomor 367/KN/2019 tentang Perubahan Ketiga Atas Keputusan Direktur Jenderal Kekayaan Negara Nomor 246/KN/2017 Tentang Petunjuk Teknis Penilaian Tanah, Gedung dan Bangunan, Jalan, Jembatan, Bangunan Air Dan Penyusunan Laporan Penilaian Dalam Rangka Penilaian Kembali Barang Milik Negara

Kieso, D.E, Weygandt, Jerry.J, \& Warfield, Terry.D. (2017). Intermediate Accounting 3th Edition. USA: John Wiley \& Sons, Inc.

KPKNL Sorong (2018). Laporan Penilaian Kembali BMN Pengadilan Negeri Manokwari Tahun 2018.

Nugrahani, C. (2014). Fair value dan potensi fraud. Kiat BISNIS, 5(5), 325-333.

Republik Indonesia. Peraturan Presiden Nomor 75 Tahun 2017 tentang Penilaian Kembali Barang Milik Negara/Daerah. 
Republik Indonesia. Peraturan Pemerintah Nomor 71 Tahun 2010 tentang Standar Akuntansi Pemerintah.

Republik Indonesia. Undang-Undang Nomor 17 Tahun 2003 tentang Keuangan Negara.

Republik Indonesia. Undang-Undang Nomor 1 Tahun 2004 tentang Perbendaharaan Negara.

Pascayanti, Y., Rahman, A. F., \& Andayani, W. (2017). Relevansi Nilai Atas Nilai Wajar Aset dan Liabilitas Dengan Mekanisme Good Corporate Governance Sebagai Variabel Pemoderasi. Jurnal InFestasi, 13(1), 227 - 242.

Sinaga, J. (2017). Kondisi Pencatatan Aset Tetap Yang Dialihkan Sehubungan Penyerahan Kewenangan Pemerintah Kabupaten/Kota Kepada Provinsi. Diakses dari situs https://www.ksap.org/sap/kondisi-pencatatanaset-tetap-yang-dialihkan-sehubunganpenyerahan-kewenangan-pemerintahkabupatenkota-kepada-provinsi/ diakses tanggal 23 Februari 2020.

Sonbay, Y. Y. (2010). Perbandingan biaya historis dan nilai wajar. Kajian Akuntansi, 2(1), 1 - 8. 